\title{
Inés Lloréns, La “diakonia” de la forma del matrimonio. La forma canónica al servicio de la realidad matrimonial, EUNSA, Pamplona 2020, 470 pp.
}

A Igreja reconheceu desde o seus começos, que a causa eficiente do matrimônio é o consentimento dos cônjuges, legitimamente manifestado. Somente sua vontade pode dar origem ao vínculo matrimonial, uma vontade que nenhum outro poder pode fornecer. No entanto, a celebração do matrimônio vai muito além da mera esfera privada. $\mathrm{O}$ casamento é um acontecimento eminentemente social e festivo que diz respeito não só a vida dos cônjuges, mas também as vidas das famílias que se unem e a vida de toda a sociedade civil e eclesial. Por conseguinte, é lógico e natural que a sua celebração goze de um certo reconhecimento que permite aos mesmos cônjuges reconhecer a vontade do outro e que, por sua vez, permitindo a toda a comunidade, eclesial e civil a que pertencem, identifique $o$ nascimento dessa nova família.

Durante séculos, a obrigação da forma canônica tem se revelado como um instrumento adequado para verificar essa vontade matrimonial, daí a sua exigência ad validitatem desde o Concílio de Trento. Após algumas oscilações na legislação que tem procurado

\footnotetext{
${ }^{1}$ Doutor em Direito Canônico Pontifícia Universidade Santa Cruz de Roma com uma tese sobre o Direito Canônico matrimonial. Atualmente é pároco da Paróquia de São Vicente Ferrer em Godoy Cruz, Mendoza, e Vigário Judicial Adjunto do Tribunal Interdiocesano de Mendoza.
} 
encontrar o equilíbrio entre a necessária segurança jurídica e a facilitação do direito ao matrimônio, Benedicto XVI com o Motu próprio Omnium in mentem decidiu optar pela garantia da certeza: todos os católicos estão vinculados à forma canônica, independentemente da sua vontade de pertencer ou não à Igreja.

Diante dessa situação, Lloréns se questiona a seguinte pergunta: qual o papel da forma canônica na formação do matrimônio? Sua executoriedade ad validitatem, estaria limitando o poder soberano das partes contratantes? As razões que levaram à exigência de uma certa forma de celebração em Trento, justificam hoje em dia que um consentimento naturalmente válido seja ignorado se não tiver sido dado de acordo com a forma prescrita? (p.22).

O título e o subtítulo da obra permitem ao leitor destacar o conteúdo da obra de Inés Lloréns, professora de direito matrimonial da Pontifícia Universidade de Santa Cruz. Todo o estudo gira em torno da concessão da forma ao serviço da verdade do matrimônio.

Estamos diante de um volume de grande profundidade jurídica, com sólido conteúdo proposicional. O livro tem prefácio do professor Carlos J. Errázuriz.

O trabalho está dividido em cinco capítulos distribuídos em duas partes. Na primeira parte, que engloba os três primeiros capítulos, a autora aborda a função que a forma jurídica desenvolveu ao longo da história. Os momentos mais significativos são estudados detalhadamente: das origens da Igreja ao século XV (Capítulo I); do Concílio de Trento ao Motu Proprio De Crebrae Allatae (Capítulo II) e do Concílio Vaticano II ao Motu Proprio De Concordia inter Codices (Capítulo III). Este detalhado estudo histórico-jurídico permite à autora fazer uma série de perguntas as quais responderá de forma satisfatória ao longo da obra, principalmente no capítulo $\mathrm{V}, \mathrm{o}$ qual é como uma grande conclusão de todo o caminho percorrido.

A segunda parte do trabalho é um estudo sistemático da função da forma canônica. No primeiro capítulo desta seção, Capítulo IV, a autora aborda o princípio formal do matrimônio. 
É evidenciada a relação íntima que existe entre os princípios presentes no sistema matrimonial da Igreja: o princípio formal, o princípio consensual, a segurança jurídica e o ius connubii.

Nesse sentido, Lloréns afirma que "a forma canônica exerce, no que diz respeito ao matrimônio, uma função diaconal estrita; isto é, a razão de sua existência é justamente servir ao exercício do ius connubii. Portanto, é importante que o Legislador conceba as formas mais respeitosas de recepção do direito fundamental ao matrimônio. Deve procurar uma forma de acolhimento que permita um equilíbrio entre a proteção e promoção dos direitos fundamentais dos fiéis e os demais direitos legais que possam estar em jogo"(p. 283).

O quinto capítulo é uma proposta em que Inés Lloréns, com grande expertise e na trilha traçada por outros autores (Errázuriz, Ortiz), propõe a forma canônica ad liceitatem como garantia suficiente dos princípios em jogo: segurança jurídica, favor matrimonii, e ao mesmo tempo, respeitoso do ius connubii.

Ao longo da monografia, a autora destaca constantemente a utilidade não só da forma jurídica, mas de todo o sistema do direito matrimonial, e remete essas duas realidades para o propósito evangelizador da Igreja.

Uma intervenção da autoridade eclesiástica neste sentido (exigindo a forma ad liceitatem) faria muito mais uso da forma canônica como instrumento evangelizador: o anúncio da boa nova do matrimônio e da família.

Uma vasta e completa bibliografia no final do volume (pp. 427-470) dá ao leitor a possibilidade de se aprofundar mais neste e em outros tópicos relacionados à lei canônica do matrimônio. 